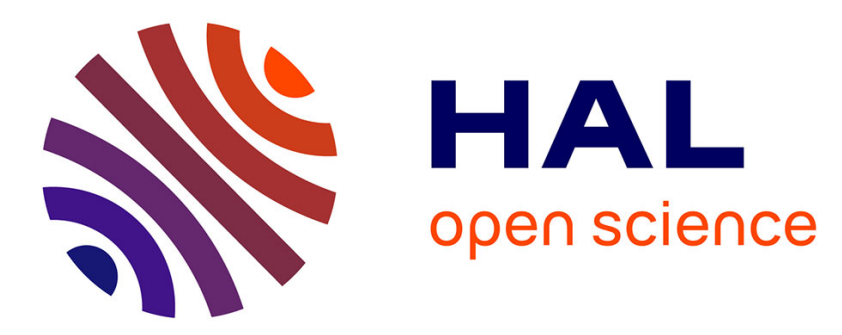

\title{
Detrital rutile ages can deduce the tectonic setting of sedimentary basins
}

Inês Pereira, Craig Storey, Robin Strachan, Telmo Bento dos Santos, James

Darling

\section{> To cite this version:}

Inês Pereira, Craig Storey, Robin Strachan, Telmo Bento dos Santos, James Darling. Detrital rutile ages can deduce the tectonic setting of sedimentary basins. Earth and Planetary Science Letters, 2020, 537, pp.116193. 10.1016/j.epsl.2020.116193 . hal-03021779

HAL Id: hal-03021779

https://hal.uca.fr/hal-03021779

Submitted on 24 Nov 2020

HAL is a multi-disciplinary open access archive for the deposit and dissemination of scientific research documents, whether they are published or not. The documents may come from teaching and research institutions in France or abroad, or from public or private research centers.
L'archive ouverte pluridisciplinaire HAL, est destinée au dépôt et à la diffusion de documents scientifiques de niveau recherche, publiés ou non, émanant des établissements d'enseignement et de recherche français ou étrangers, des laboratoires publics ou privés. 
1 Detrital rutile ages can deduce the tectonic setting of sedimentary basins

2

3 Inês Pereira ${ }^{1^{\star}}$ Craig Storey ${ }^{1}$ Robin Strachan ${ }^{1}$ Telmo Bento dos Santos ${ }^{2,3}$ James

$4 \quad$ Darling $^{1}$

51 School of the Environment, Geography and Geosciences, University of Portsmouth,

6 Portsmouth, PO1 3QL, Hampshire, United Kingdom

$7 \quad{ }^{2}$ FCUL - Faculdade de Ciências, Universidade de Lisboa, Campo Grande, 1749-016, Lisboa,

8 Portugal

$9{ }^{3}$ Instituto Dom Luiz (IDL), Faculdade de Ciências, Universidade de Lisboa, Campo Grande,

10 1749-016, Lisboa, Portugal

11 *corresponding author: ines.pereira@port.ac.uk

Graphical abstract

14

15

16

17

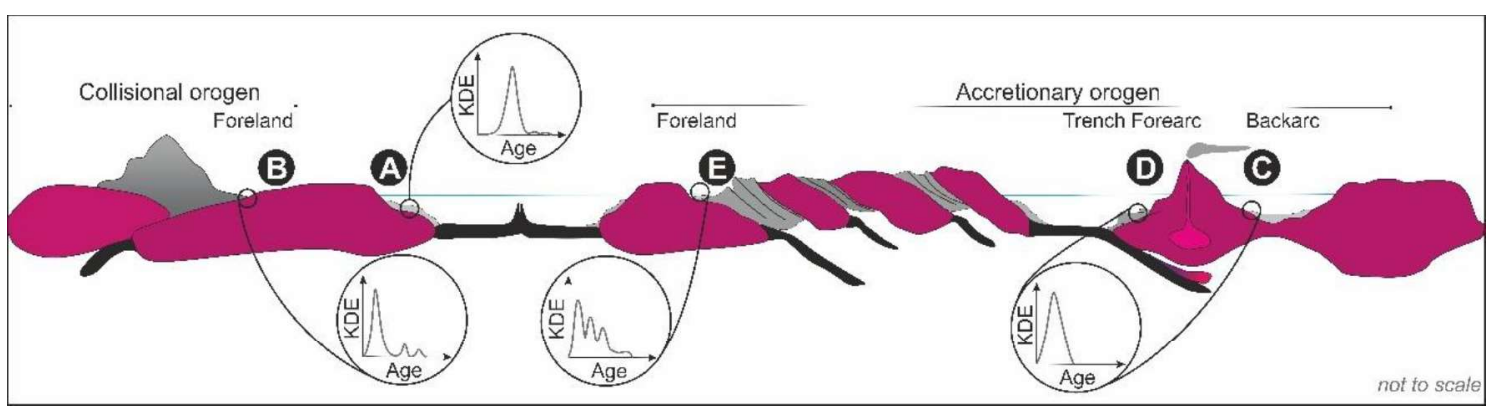

Highlights

- Detrital rutile age distributions are sensitive to tectonic environments

- A new tool to discriminate the tectonic setting of sedimentary basins

- Rutile can distinguish different foreland basins and extensional settings

- We test this tool using well-characterised Precambrian basins

- This tool might be applied to units that endured tectonothermal overprinting events

Abstract

Sedimentary sequences contain a detailed record of the evolution of the Earth's surface. Detrital mineral grains provide, for example, evidence of source redox 
conditions, insights into the age, geochemistry and petrology of basement sources and can also be used to elucidate tectonic environments. Detrital zircon has been used as a means of analysing the tectonic setting of host sedimentary successions, but with potentially ambiguous results. It is important to find additional ways to discriminate depositional settings, particularly in Precambrian sequences where other proxies are either not available or have been lost. In this contribution we provide a new way to discriminate between different sedimentary tectonic environments using the mineral rutile. We present a large compilation of detrital rutile data to show that the $\mathrm{U}-\mathrm{Pb}$ age distribution is sensitive to the tectonic setting of the basin in which the host sediments were deposited. We then apply this new approach to two case studies, where the depositional setting and age are well-constrained: siliciclastic units of NW Scotland which were deposited in the Neoproterozoic foreland of the Grenville Orogen and on the Cambrian passive margin of the lapetus Ocean, and the Brazilian Sabará basin located within the Palaeoproterozoic foreland of the Minas orogen. We compare the detrital rutile and zircon age distributions of these successions, showing that in some cases they are different, and that rutile is most sensitive to the youngest metamorphic events affecting the sources, reinforcing the applicability of this tool. By testing this new method on polyphasally-deformed successions (Sabará basin) we show that detrital rutile can still inform the tectonic setting even at medium grades of metamorphism.

Keywords: plate tectonics; sedimentary basins; rutile; foreland; tectonic discrimination

\section{INTRODUCTION}

Although modern sedimentary basins only account for $16 \%$ of the terrestrial land surface, river catchments drain $67 \%$ of the global non-glaciated land surface to a terrestrial sink (Nyberg et al., 2018), thus making the terrestrial sedimentary record highly representative of the exposed continental crust at the time of deposition. As the 
sedimentary record goes back as far as $3.8 \mathrm{Ga}$ (Fedo et al., 2001) and is more temporally complete than the igneous record (Cavosie et al., 2005), it is a repository of valuable geological information. It has provided, for example, evidence related to the evolution of the continental crust (Dhuime et al., 2017) and the nature of now-vanished Hadean crust (Cavosie et al., 2005).

With the increasing ability of many laboratories to analyse and process large amounts of geochronological data, detrital zircon studies have proliferated. Multiisotopic proxies in zircon, including $\mathrm{U}, \mathrm{Pb}, \mathrm{Th}, \mathrm{Hf}, \mathrm{O}$, can provide insight into not only age of crystallisation, but also magma composition, timing of extraction of the source from the depleted mantle reservoir, and constraints on crustal recycling, which have helped to understand early Earth processes (e.g. Bradley, 2011; Condie and Kröner, 2013). Detrital zircon studies have contributed towards paleogeographical reconstructions (e.g. Belousova et al., 2002; Mulder et al., 2018), and have been used to elucidate tectonic settings of sedimentary basins (Cawood et al., 2012).

However, information derived from detrital zircons can bias our understanding of the evolution of continents and sedimentary basins, as it preferentially records synto late-orogenic felsic magmatism (e.g. Condie, 2014; Spencer et al., 2015). Generation of zircon-bearing felsic magma can also take place during rifting and lithospheric extension, which leads to uncertainties when applying tectonic discrimination diagrams based on zircon. In the absence of fossils and environmentalspecific markers, determining depositional tectonic settings in Precambrian sequences is challenging and thus it is important to find new proxies. An alternative way of tackling this problem is by looking at other components of the detrital record that form as a response to tectonic processes, such as metamorphic minerals, which may provide a clearer link to convergent and collisional-related basins.

Convergent- or collisional-related tectonics generally results in regional Barrovian-style metamorphism, in contrast to extensional tectonics where any associated metamorphism (if present at all) is low-pressure in nature (Robinson, 1987). 
81 Therefore, by using a metamorphic mineral that is stable at a wide range of pressures

82 and temperatures, mechanically and chemically robust, can endure sedimentary cycles

83 of transport and diagenesis, and is amenable for high-resolution isotopic dating, it may

84 be possible to discriminate between sedimentary basins formed in convergent/collisional and extensional settings.

Rutile is commonly found in siliciclastic rocks and, together with zircon and tourmaline, can be used to define a sediment maturity index (Hubert, 1962). Rutile can grow in a range of P-T metamorphic conditions (e.g. Angiboust and Harlov, 2017; Liou et al., 1998; Hart et al., 2018), but more rarely at greenschist and amphibolite facies (Luvizotto et al., 2009b). Rutile is therefore expected to form commonly during subduction and collision associated with orogenesis and less frequently during extensional tectonics. In continental collision zones, higher pressure and temperature conditions tend to exceed the conditions for $\mathrm{Pb}$ retentivity in rutile (Cherniak, 2000), affecting a large portion of the continental crust. These conditions largely promote the resetting of the $\mathrm{U}-\mathrm{Pb}$ isotopic system and new growth of rutile over a relatively short period of time (a few tens of myr). In contrast, accretionary orogens are generally characterised by multiple arc collision events over a longer time frame (potentially hundreds of myr), and are, therefore, likely to result in a more complex rutile age record, comprising multiple sets of metamorphic ages.

In this contribution, we analyse published and new detrital rutile data to show that it can be used to deduce the tectonic setting of sedimentary basins. This new compilation dataset includes detrital rutile from multiple different geographical areas, from both sedimentary rocks and stream sediments. These cover a range of tectonic settings from rift to passive margin, backarc, forearc, accretionary and collisional foreland basins, developed across a wide span of geological time. We apply this new tool to two well-characterised sedimentary units in NW Scotland, with different depositional ages and tectonic settings, whose provenance is relatively wellcharacterised. In order to test the suitability of this approach to analysing 
(meta)sedimentary units with a polyphase tectonometamorphic history we also apply it to sediments deposited in a foreland basin in Brazil during the Palaeoproterozoic.

114 Rutile and zircon can record different aspects of crustal recycling and growth, zircon mostly providing the timing of high-temperature processes, while rutile records peak metamorphism and/or exhumation/cooling histories. In extensional settings, contemporary A-type magmatism can contribute zircon to sedimentary basins (Fig. 1A). However, rutile mostly results from metamorphic reactions and hence would not be expected to form any substantial component of the detrital population in this setting. In collisional settings, due to the higher $\mathrm{Pb}$ closure temperature of zircon relative to rutile (zircon in excess of $900^{\circ} \mathrm{C}$ while rutile at $570{ }^{\circ} \mathrm{C}$, for grains of $100 \mu \mathrm{m}$ and $1^{\circ} \mathrm{C} / \mathrm{Ma}$ cooling rates; Cherniak, 2000), zircon ages may include a substantial inherited component (Fig. 1B), whereas rutile often exhibits a distribution curve that reflects the age of the youngest metamorphic event(s) (Fig. 1B).

The frequency age distribution of detrital rutile thus seems to reflect the tectonic depositional environment during the infill of a sedimentary basin. Data from this first large compilation of rutile analyses (Appendix A) are summarised and presented in Figure 2, as a schematic model of the predicted Kernel density estimate (KDE) curves for different tectonic settings.

In convergent-related basins, the rutile KDE's theoretically present a Gaussian distribution curve with the main age peak quite close to the depositional age (Fig.2-C, D). A more significant rutile population can be expected in association with the accretionary prism in the forearc in comparison with the back of the arc. However, if any rutile is forming due to Barrovian metamorphism imposed on the upper plate, rutile ages from both settings will display a similar Gaussian distribution curve. A similar distribution can be expected from extensional settings, particularly when the detrital 
137 rutile population came from a metamorphic source that endured a complete $\mathrm{U}-\mathrm{Pb}$ rutile

138 resetting. This imparts a unimodal distribution curve, but with the main age peak older 139 than depositional age (Fig. 2-A). Nonetheless, this distribution curve is mostly dependent on the tectonometamorphic events that have affected the source area basement, and could be more complex, with multiple rutile populations instead of just one main age peak.

In foreland basins, two types of KDE's can be expected, resembling either a convergent-related KDE (Fig. 2-B) or a multimodal KDE distribution, which reflects only partial resetting in a protracted accretionary history (Fig. 2-E).

2.2. Detrital rutile cumulative proportion ages and depositional tectonic environments plots in fields which do not correspond to the true depositional setting of either basin.

To investigate further the suitability of rutile as a proxy in elucidating tectonic environments, we apply the cumulative proportion approach to detrital rutile $\mathrm{U}-\mathrm{Pb}$ age data. We compare data from different basins, plotting the cumulative proportions of detrital minerals against the growth age minus the estimated depositional age (Fig. 3). This is the same procedure as used by Cawood et al. (2012) for detrital zircon, showing steep curves for collisional-related basins and smooth curves, with large gaps between deposition and growth age for extensional-related basins.

A large compilation of detrital rutile $\mathrm{U}-\mathrm{Pb}$ data is presented as supplementary data (Appendix A), combining sedimentary basins and stream sediment examples associated with different tectonic settings and depositional ages. Cumulative distributions of both rutile and zircon from a backarc and a foreland basin examples are projected in Figure 3 to compare the record from these different minerals. Rutile invariably shows a different distribution to that of zircon, with rutile overlapping quite well with the predicted tectonic field diagram from Cawood et al. (2012), while zircon Thus, it seems that the cumulative distributions of rutile are better proxies than detrital 
zircon for discriminating tectonic environments, due to the significant overlap between the different tectonic fields (Cawood et al., 2012), which is a consequence of zircon not being so sensitive to metamorphic processes, and to zircon growth during extensionalrelated magmatism (Fig. 1A).

Therefore, due to its metamorphic nature and lower $\mathrm{Pb}$-closure temperatures, rutile appears to provide a better means of distinguishing between tectonic environments. In combination with detrital zircon, rutile will lead to better discrimination of depositional tectonic environments in units preserved at low to medium metamorphic grade (sub-upper amphibolite facies). In the next sections, we examine rutile U-Pb datasets from extensional-related, convergent-related and foreland basins.

\subsubsection{Extensional basins: rift-passive margins}

In extensional settings, rift basins can evolve to passive margin oceanic basins (Fig. 2A) or infill to produce an aulacogen. Metamorphic rutile is not commonly formed in these settings, and thus this should be reflected in the difference between growth and deposition age. This is the case of a stable continent undergoing extension, such as in North Africa (Nile drainage system during the Cenozoic; Fielding et al., 2018) or in eastern North America (North Carolina; O'Sullivan et al., 2016) where most rutile ages that are significantly older than the depositional age (Fig. 4-A).

Thus, passive margin sediments can typically show an "S" distribution curve, if the extension stage evolved after a continental collision setting. This " $\mathrm{S}$ " shape reflects a) no or very little grains formed at the time of deposition, b) a lag that is followed by c) a range of ages contained within a relatively short period, following a Gaussian distribution age. However, due to inherent geological complexity, there are cases more difficult to unravel. For instance, after the amalgamation of Gondwana, during the Neoproterozoic Pan-African Orogeny, certain areas of Gondwana were extended to 
accommodate the Cambro-Ordovician seas that covered large areas of this supercontinent. Where rifting developed on top of the suture, we refer to these as 'suture rift' basins. The short time difference between the orogenic event and the development of these basins is reflected in the small gap/lag between the maximum depositional age of these sediments and the age of the youngest rutile (Fig. 4-A, curve 2; Rösel et al., 2014a). This, in turn, is reflected in the rutile cumulative proportion curves (Fig. 4B; Avigad et al., 2017). Cambrian rift basins in this context resemble a collisional detrital rutile KDE curve (Fig. 1B) and the cumulative proportion curve overlaps in age difference with the convergent-type curves (Fig. 5). However, as the basin evolves to a passive margin, because there is no generation of metamorphic rutile (due to the unfavourable tectonic setting) the difference between depositional and detrital mineral ages increases. This can be tracked in Cambro-Ordovician sedimentary sequences, with an acute overturn of the cumulative proportion, from base to top, shifting from more than $80 \%$ of detrital rutile within a gap of 100 myr in the Cambrian units to about $15 \%$ in an equivalent period for the Ordovician units, along with a change in the curve shape (Fig. 4B). Note that the S-shaped curve is an approximation, and that depending on drainage patterns, we should also consider the existence of an important older component decomposing the curve into a double-S shape (Fig. 4; curve 1).

We acknowledge that in certain circumstances some rutile grains may yield ages similar to the depositional age. This could result from the formation of rutile during hydrothermal activity and/or contact metamorphism or from the resetting of the U-Pb isotopic system during margin hyperextension and basement exhumation. Nonetheless, in most documented examples these relatively young rutile grains only form a minor component of the detrital rutile population (e.g. Odlum et al., 2019).

\subsubsection{Supra-subduction basins}


220 Clastic sediments deposited in supra-subduction convergent basins are not commonly 221 preserved under low metamorphic conditions, as they are often involved in collisional processes during the ensuing assembly of continents. Typical basins that form at these stages are forearc and backarc basins. Due to the very restricted source availability, usually confined to the exposed arc and potentially the accretionary prism during thickening and thrusting, these basins tend to reflect a unimodal distribution age and the youngest detrital mineral is very close in age to the depositional age (Fig. 2-C,-D). This is the case, despite the small number of rutile grains, of a forearc basin related to the Variscan orogeny (Turkey; Okay et al., 2011) and a backarc basin of Palaeoproterozoic age (Western Australia; Rösel et al., 2014b), showing a very steep rutile cumulative proportion curve with nearly the entire population contained within 100-150 Ma of deposition age. The cumulative age distribution curve resembles more of a " $r$ " in these settings (Fig. 5, curves 1,2).

\subsubsection{Foreland basins}

Foreland basins develop during collisional orogenesis, associated with accretionary orogens such as arc-continent collision, Cordillera-type or Himalayan-type, collisional orogens (Fig. 2-B,-E). The detrital population distribution in each of these cases reflects its context. The foreland basins of continental collision orogens mainly gather detrital minerals formed as a consequence of very large-scale collision, capturing similar ages with Gaussian age distributions (i.e. recording one main tectonometamorphic event). This is the case for the Pan-African Orogeny (e.g. Avigad et al. 2017), recorded in several different basins that accumulated Cambrian sedimentary units deposited during subsequent rifting. A nearly Gaussian age distribution with some inheritance is also a plausible age distribution, such as the detrital rutile distribution associated with the 
246 Himalayan foreland (Fig. 1B). The rutile cumulative proportion distribution ages

247 collected from stream and river sediments in this foreland (Bracciali et al., 2015; 2016)

248 show that about $80 \%$ of all grains are within 50 Ma of depositional age, with a smaller

249 inherited component. This can be evaluated in the cumulative proportion distribution as

250 an almost linear curve with a progressive increase in the age difference (Fig. 5, curve

251 3). The difference between this curve and the Pan-African-type described above is

252 most likely a reflection of the collisional stage at the time of deposition. We can predict

253 that as more of the lower crust is exhumed due to the collisional process, more

254 Himalayan-age metamorphic rutile will reach the foreland basin. This should balance

255 the cumulative proportion curve to nearly $100 \%$ within the orogenic period, favouring a

256 Gaussian age distribution.

257 In the case of accretionary orogens, such as the Cordillera along the eastern margin of the Pacific Ocean, a protracted series of arc-continent collisions will typically result in episodic and prolonged tectono-thermal events and in a multimodal detrital rutile age population (Fig. 2-E). This is shown by the cumulative proportion distribution curves of detrital rutile from the Cretaceous Sevier foreland basin sequences in Utah and Wyoming (Lippert 2014; Fig. 5-curves 4, 5). In this example, there is a nearly continuous generation of metamorphic rutile, with growth age similar to depositional age. Yet, instead of a linear and steep cumulative proportion distribution increase, there is rather a continued stepped growth curve, reflecting a prolonged, but episodic tectonometamorphic history of the source terranes. The gap between depositional age and the youngest rutile ages in the Sevier foreland reflects two different tectonic processes; for the Utah sequence, out of sequence thrusting exposes older basement (white dashed line, Fig. 5), preventing new rutile from reaching the basin, while in the Wyoming sequence, deposition during segmentation of the basin allowed new rutile to 271 reach the foreland. 
277 In order to further test the applicability of rutile to the discrimination of tectonic settings of sedimentary basins, we collected new zircon and rutile U-Pb data from three

279 different stratigraphic units, two of which represent foreland basins and the third a passive (extensional) margin basin. Two crop out in NW Scotland, the late Mesoproterozoic to early Neoproterozoic Torridon Group and the Cambrian Ardvreck Group. The third unit crops out in the Quadriláterro Ferrifero in Brazil, the Sabará Formation in the Minas Supergroup. Sample locations, stratigraphic sections and lithological descriptions are presented in Appendix B.

The depositional age of the Torridon Group is constrained to between $997 \pm 39$ Ma and $1049 \pm 46 \mathrm{Ma}$, and it is interpreted as the siliciclastic infill of the foreland basin of the Grenville orogen (Rainbird et al. 2001; Krabbendam et al. 2017). One sample was collected from the basal Diabaig Formation, and three from the Applecross Formation. The depositional age of the Ardvreck Group is early Cambrian, older than $520 \mathrm{Ma}$ (see Cawood et al. 2007 for details) and it is believed to have accumulated on the extended Laurentian passive margin of the lapetus Ocean (McKie, 1990). Three samples were collected from Ardvreck Grp., two from the Basal Quartzite Member and one from the Pipe Rock Member. The Sabará Formation (Minas sequence) in Brazil has been interpreted to represent the foreland basin of the Palaeoproterozoic Minas Orogen, deposited during the Rhyacian (Alkmim and Marshak, 1998). Two samples were obtained from the basal metaconglomerate unit.

3.2 Methods

Zircon and rutile U-Pb isotopic data were acquired using an ASI RESOlution 193nm 
at the University of Portsmouth. A summary of the instrumental setup, ablation parameters and conditions can be found in supplementary data (Appendix B).

U-Pb rutile analyses were performed during different analytical sessions with variable parameters, such as spot sizes ranging from 35 to $40 \mu \mathrm{m}$, with a laser energy density between 4 and $4.2 \mathrm{~J} / \mathrm{cm}^{2}$ at a repetition rate of $5 \mathrm{~Hz}$. A sample-standard bracketing method was used to correct mass fractionation using R10 rutile as a primary standard (average ID TIMS age of $1091.3 \pm 4.7 \mathrm{Ma}$; Luvizotto et al., 2009a), and three different secondary standards were analysed; R13 (SIMS age of $504 \pm 4$ Ma; Schmitt and Zack, 2012), R19 (ID TIMS age of $493 \pm 10 \mathrm{Ma}$; Zack et al., 2011) and SAE (unpublished, ID TIMS $495 \mathrm{Ma}$, provided courtesy of C. Lana, UFOP). Calculated ${ }^{206} \mathrm{~Pb} /{ }^{238} \mathrm{U}$ weighted mean average ages for R13 and R19 secondary standards are within $1.2 \%$ accuracy of the reported ages (Appendix $\mathrm{C}$ ). $\mathrm{U}-\mathrm{Pb}$ dating of rutile is more difficult than zircon due to overall low $U$ concentration ( $<100 \mathrm{ppm})$ and incorporation of small amounts of $\mathrm{Pb}$ at the timing of growth. Common- $\mathrm{Pb}$ corrections are not always applicable and natural discordance complicates this further. Filtering these datasets to include only grains that are more than $95 \%$ and lower than $105 \%$ concordant excludes many grains from these datasets and reduces some of these samples to smaller populations. This might generate a bias in terms of determining precise ages of events, but it is unlikely to have a great effect on the cumulative distributions and the overall distribution curves. No common-Pb corrections were applied.

Zircon $\mathrm{U}-\mathrm{Pb}$ analyses were performed based on cathodoluminescence images, obtained in a ZEISS EVO10MA Scanning Electron Microscope, in two different sequences using $20 \mu \mathrm{m}$ ablation spots, with a laser energy density of $3 \mathrm{~J} / \mathrm{cm}^{2}$ at a repetition rate of $2 \mathrm{~Hz}$. A sample-standard bracketing method was used to correct for mass fractionation using BB9 zircon as a primary standard (average ID TIMS age of $560 \pm 5 \mathrm{Ma}$; Santos et al., 2017), and two different secondary standards were analysed; 91500 zircon (ID-TIMS of $1065 \pm 5$ Ma; Wiedenbeck et al., 1995) and KAAP 
Valley tonalite zircon (SHRIMP age yielding $3226 \pm 14$ Ma; Armstrong et al., 1990). A concordia age yielding $1050.4 \pm 4.9 \mathrm{Ma}$ for 91500 and an upper intercept age of $3222 \pm$ $28 \mathrm{Ma}$ for Kaap Valley tonalite zircon are within uncertainties of reported ages (Appendix D).

All data were processed using the software package IOLITE 3.31. Concordia, weighted mean average ages, age frequency histograms and cumulative probability distributions were calculated using ISOPLOT/EX 4.1 (Ludwig, 2009), detzrcr Rpackage (Andersen et al., 2018) and Microsoft Excel. Statistical tests applied to the detrital populations were conducted using DZstats, a Matlab-based application (Saylor and Sundell, 2016). New U-Pb data is presented as supplementary data (Appendix C and D).

\section{RESULTS AND DISCUSSION}

Detrital rutile and zircon $\mathrm{U}-\mathrm{Pb}$ ages are presented and discussed using only the $\pm 5 \%$ discordant data, which increases the confidence in the ages used and their significance. This is particularly relevant for Palaeoproterozoic, Archaean and Hadean mineral ages, where variable degrees of $\mathrm{Pb}$-loss or age mixing can produce concordant isotopic ratios but meaningless geological ages (Pereira et al., 2019). ${ }^{206} \mathrm{~Pb} /{ }^{238} \mathrm{U}$ ages are used for ages of $<1000 \mathrm{Ma}$ and ${ }^{207} \mathrm{~Pb} /{ }^{206} \mathrm{~Pb}$ ages are used for ages of $>1000 \mathrm{Ma}$. We apply cross-correlation metrics to assess similarity or dissimilarity between different populations (Saylor and Sundell, 2016).

\subsection{The NW Scotland case study}

The new detrital rutile $\mathrm{U}-\mathrm{Pb}$ age data presented here for the Torridon and Ardvreck groups are integrated with published $\mathrm{U}-\mathrm{Pb}$ analyses. The U-Pb zircon ages of the Applecross Formation are those reported from Lancaster et al. (2011) and zircon and 
rutile U-Pb data from Krabbendam et al. (2017), while for the Diabaig Formation our new detrital U-Pb ages for both zircon and rutile (Appendix C, D) are combined with the zircon data of Kinnaird et al. (2007). For the Ardvreck Group, zircon data has been compiled from Cawood et al. (2007) and Lancaster et al. (2011). CL zircon images are shown in appendix $\mathrm{E}$.

\subsubsection{Late Mesoproterozoic to early Neoproterozoic Torridon Group}

From the Torridon Group, we analysed samples of the Diabaig Formation and the Applecross Formation. From the Diabaig Formation (Fig. 6A and C) we analysed 55 rutile grains, retrieving 35 concordant grains, and 135 zircon grains (103 grains were concordant). The youngest rutile in the Diabaig Formation is $1089 \pm 29 \mathrm{Ma}(4 \%$ discordant) whilst the oldest rutile is $1896 \pm 25 \mathrm{Ma}(1 \%$ discordant $)$. From the Applecross Formation (Fig. 6B and D) we analysed 266 rutile grains (145 concordant grains) and combined them with 275 zircon grains (191 concordant grains). The youngest rutile in the Applecross Formation is $1018 \pm 50 \mathrm{Ma}$ ( $0 \%$ discordant) whilst the

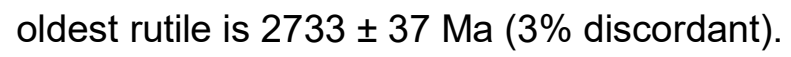

By applying different statistical tests, including cross-correlation, Likeness and Similarity tests (as in Saylor and Sundell, 2016), we demonstrate that the frequency distribution of both rutile populations from the Torridon Group are significantly similar (Table 1).

As for the detrital zircon datasets, both units have different population distributions: the Diabaig Formation exhibits a significant Neoarchaean age peak, while the Applecross Formation shows a multimodal distribution, with a major age peak between 1.8 and $1.65 \mathrm{Ga}$. The oldest zircon grain is found in the Diabaig Formation yielding an age of $3495 \pm 19$ Ma ( $3 \%$ discordant). This is supported by the statistical tests, showing low cross-correlation coefficients (Table 1) between these detrital zircon populations. 

localised basins that developed immediately above the regional unconformity with the underlying Lewisian Gneiss Complex (Kinnaird et al., 2007; Stewart, 2002). In this context, it might be expected that the sediments would preserve a close record of the dominant Archaean-Palaeoproterozoic tectonothermal events that characterise this basement. However, the presence of many Mesoproterozoic-aged rutile grains in both the Diabaig and the Applecross formations indicates a more distal source from the Lewisian Gneiss Complex which lacks such Mesoproterozoic ages. This is consistent with the general westerly source invoked for the Torridon Group as a whole (Stewart, 2002; Kinnaird et al., 2007: Krabbendam et al., 2017). The evolution of the DiabaigApplecross basin appears to have favoured the inclusion of increasingly younger detritus up-section, presumably more distal. Thus, the proportion of late Archaean material decreases upwards at the expense of increasing proportions of Palaeo- and Mesoproterozoic zircon and rutile grains.

The cumulative probability curves of rutile and zircon in the Diabaig Formation 401 (Fig. 6C) are quite different from those for the Applecross Formation (Fig. 6D) and 402 supported by the low cross-correlation coefficients (Table 1). While in the Applecross Formation dataset, the differences between rutile and zircon can be explained by their contrasting closure temperatures, with zircon recording crystallisation/metamorphic ages while rutile records exhumation and cooling, this is not plausible for the Diabaig Formation curves. Two different hypotheses could explain these differences: 1) a variation in the proportions of detritus eroded from two distinct basement sources (e.g. Archaean Lewisian Gneiss Complex and a metamorphic Mesoproterozoic source), or 2) a complete resetting of U-Pb systematics in existing rutile and/or growth of new rutile in a single reworked basement source of Archaean age. The former would imply 411 distinct palaeocurrents, which would carry sediments from multiple sources. This is 412 inconsistent with the main easterly-flowing palaeocurrents recorded within the Diabiag and Applecross successions (Stewart, 2002), despite some local variability in Diabaig 
414 palaeocurrents. The second hypothesis implies a variation in the basement source 415 area from the Diabaig to Applecross formations. A feasible interpretation is that the 416 Diabaig Formation contains detritus derived from external sectors of the Grenville belt 417 characterised by Archaean protoliths that had been reworked at 1.6-1.0 Ga (such as 418 the Gagnon Terrane; van Gool et al., 2008). This source would contribute mostly 419 Archaean zircon and Proterozoic metamorphic rutile. As fluvial systems progressively 420 cut back into the orogenic hinterland they would have eroded younger accreted 421 Ketilidian/Labradorian terranes that had also potentially been reworked at this time.

422 This source would then also contribute Proterozoic zircon and thus explain the shift of zircon age peaks as seen from the Diabaig to the Applecross formations. These variations can be envisaged in terms of protolith fertility (for zircon and/or rutile) and mixing of detrital components from variable sources in the eastern Grenvile Province.

\subsubsection{Cambrian Eriboll Formation}

Three samples from the basal siliciclastic unit of the Ardvreck Group were collected, 430 including the Basal Quartzite Member (BQ; Fig 7A and $C$ ) and the bioturbated Pipe Rock Member. (PR; Fig 7B and D). From the BQ, we collected data from 263 rutile grains retrieving 112 concordant grains and combined them with 123 zircon grains (81 concordant grains). The youngest rutile in $\mathrm{BQ}$ is $1006 \pm 78 \mathrm{Ma}$ (5\% discordant), yet the youngest cluster occurs at ca. $1.6 \mathrm{Ga}$. The oldest rutile is $2953 \pm 36 \mathrm{Ma}(3 \%$ discordant). In the PR we collected data from 222 rutile grains (120 concordant grains) and combined them with 158 zircon grains (99 of which were concordant). The youngest rutile in PR is $1526 \pm 98 \mathrm{Ma}$ (2\% discordant) whilst the oldest rutile is $2755 \pm$ $96 \mathrm{Ma}(2 \%$ discordant). different statistical tests (Table 1). The very minor late Mesoproterozoic rutile grain 
contribution disappears from $\mathrm{BQ}$ into $\mathrm{PR}$, with a proportional increase of Archaean age rutile. The detrital zircon populations, however, show a different distribution to that of rutile, yielding low cross-correlations (Table 1).

In $B Q$, detrital zircon yields only Archaean ages. In $P R$, the Eo- and Palaeoarchaean populations decrease in favour of an increasing late Palaeoproterozoic source. The cumulative probability curves of BQ (Fig. 7C) are distinct from the PR equivalent (Fig. 7D). Rutile and zircon distribution curves are statistically different (table 1) but, considering their differences, both units show a similar variation. In $B Q$, the difference between the lower and upper quartiles for both is of about the same range of time, ca. $200 \mathrm{Ma}$, with absolute ages shifted between rutile and zircon. These can be interpreted as near complete resetting of the rutile population in the source of $B Q . P R$ is different, with both detrital minerals exhibiting two important modes and a generalised increase of younger Mesoproterozoic rutiles. There are two options for interpreting these observations: either near complete resetting and/or cooling of the late Palaeoproterozoic source of PR, or partial resetting of both the late Archaean and Palaeoproterozoic sources during the Palaeo-Mesoproterozoic.

Detrital zircons from $\mathrm{BQ}$ and $\mathrm{PR}$ have Eo- and Palaeoarchaean Hf model ages, with an important line of extraction at ca $3.3 \mathrm{Ga}$, but model crustal residence ages (TDM) as old as 3.6 and $4.0 \mathrm{Ga}$ (Lancaster et al., 2015). This indicates an older and more distal source than the mainly Neoarchaean Lewisian Gneiss Complex (Fig. 1b in Appendix B). A SE-directed paleoflow (McKie, 1990) supports a source to the NW, most probably east Greenland (Cawood et al., 2007). However, the 1.7-1.65 Ga rutile age peak can only be reconciled with this source if during the Nagssugtoqidian orogeny, rutile formed/reset in a slowly cooled terrane (to account for the ca. $150 \mathrm{Ma}$ difference between zircon and rutile ages). These ages are within the range of recently reported metamorphic rutile ages from the Nagssugtogidian in SE Greenland (Müller et al., 2018) which reinforces our interpretation. It is worthwhile noting that although the 
$\mathrm{BQ}$ samples were collected within a few metres of the underlying Applecross Formation there is no major reworking of the Torridon Group. This suggests a long period of erosion and induration of the Torridon Group prior to the Cambrian marine transgression which likely occurred relatively rapidly across a peneplained surface. The detrital rutile and zircon cumulative probability curves exhibit a well473 developed "S" shape for the Basal Quartzite Member but a more complex double-"S" 474 form for the Pipe Rock Member. The latter might be due to sourcing of basement sources that underwent a more protracted orogenic evolution, such as the terranes in Greenland. Nonetheless, both distribution curves are consistent with the extensional (passive margin) setting indicated by the geological evidence. discriminates between these two stratigraphic units from NW Scotland, thus reinforcing 480 its applicability to Archaean or Palaeoproterozoic stratigraphic sequences, and 481 illustrating how it can unravel the protracted evolution of the sources that contributed to these basins.

To verify if this tool can be applied to geologically more complex metasedimentary units, we have analysed the detrital rutile population from the Sabará Formation that was deposited during the Rhyacian in the foreland basin of the Minas orogen (Alkmim and Marshak, 1998). The maximum depositional age of this unit has been constrained at ca. $2121 \mathrm{Ma}$, a minimum depositional age of $2060 \mathrm{Ma}$ and the detrital zircon U-Pb distribution exhibits two important clusters, one at 2950-2650 Ma and another at 23202160 Ma (Martínez Dopico et al., 2017). We retrieved 59 grains from 2 samples, from which only 12 yield concordant ages (within 5\% discordance; Appendix C). Because this unit was affected by a late Neoproterozoic to Cambrian tectonometamorphic event, 
many rutile grains record variable $\mathrm{Pb}$-loss with a lower intercept age of $490 \pm 30 \mathrm{Ma}$ (MSWD = 0.66; Fig. 8A) compatible with the collapse stages of the Brasiliano event. By combining Tera-Wasserburg ${ }^{207} \mathrm{~Pb} /{ }^{206} \mathrm{~Pb}$ regression ages, ${ }^{207} \mathrm{~Pb} /{ }^{206} \mathrm{~Pb}$ intercept ages with naturally concordant rutile data we compare the KDE distribution of detrital rutile (this study) with that of zircon (Martínez Dopico et al. 2017; Fig. 8B). Due to the limited number of grains, retrieved ages only partly represent the entire population. Yet, the distribution of rutile ages resembles that of zircon (Fig. 8B), with a 0.855 cross-correlation using their respective KDEs. Concordant ages are between $2929 \mathrm{Ma}$ and $2125 \mathrm{Ma}$.

The detrital rutile and zircon cumulative distributions are quite similar (Fig. 8C), resembling a cumulative distribution curve such as the Himalayan foreland (Fig. 5, curve 5). Agreement between the detrital cumulative age distribution and evidence for the synorogenic tectonic setting (Alkmim and Marshak, 1998) demonstrates the suitability of this tool applied to geologically complex settings, despite rutile being prone to partial or full resetting under higher than low amphibolite metamorphic grade conditions.

\subsection{Summary}

We have compared detrital zircon and rutile distribution ages from three sedimentary basins of known tectonic setting. In each case, the rutile distribution ages are consistent with the known tectonic setting and furthermore have provided insights into the nature and tectonothermal evolution of source regions. Rutile $\mathrm{U}-\mathrm{Pb}$ distribution ages are often offset towards the youngest recorded events, and where protolith and metamorphic conditions enable rutile growth, this mineral will better record the youngest metamorphic/magmatic event affecting the basement source prior to weathering and final deposition in the sedimentary basin. Therefore, detrital rutile cumulative distribution ages, as shown in these case-studies, are reliable in 
discriminating distinct tectono-sedimentary settings. A summary of rutile cumulative probability curves, including new data presented here, is shown in Figure 9.

\section{CONCLUSIONS}

The importance of rutile lies in its sensitivity to tectonometamorphic processes. In this contribution, we have shown how the age distribution of detrital rutile can help to elucidate the tectonic environment at the time of deposition, complementing interpretations based on detrital zircon. This powerful new tool can be applied to the geological record with the aim of identifying the tectonic settings of depositional basins, and it can also provide insight into tectonic processes affecting source terrains, as shown by our case study of the Cambrian succession in NW Scotland. In detail, it can be used to discriminate between extensional and collisional basins, and moreover different types of collision-related basins. For example, detrital rutile grains from a succession deposited in the foreland of an accretionary orogen will typically record a prolonged metamorphic history (e.g. the Sevier), while a succession deposited adjacent to a major continental collision zone will mainly record the final collision stage (e.g. the Himalaya). However, intrinsic geologic complexities such as discussed for the Sevier foreland and rifting location (e.g. Cambrian successions in North African localities) can potentially complicate understanding of the tectonic environment at the time of deposition. In such cases, we have shown how useful it may be to compare the detrital rutile cumulative proportion distribution curves of a complete sequence and characterise changes in the cumulative distribution curve shape.

By applying this new tool to Precambrian stratigraphic sequences, we provide a new means of recognising convergent and collisional basins in the geological record. This new tool is likely to be of particular value when applied to parts of the geological record characterised by only fragmentary exposure such as the Archaean and Palaeoproterozoic cratons. The detrital rutile record could therefore provide critical 
evidence towards the understanding of early Earth tectonics and basin settings, which are key in reconstructions targeting the geodynamic evolution of our planet.

\section{Acknowledgments}

IP wants to thank the University of Portsmouth for providing a PhD bursary, technical support and for funding all analytical work. Fernando F. Alkmim and Mike Dunk are thanked for support during fieldwork. TBS was supported by FCT-Project UID/GEO/50019/2019—Instituto Dom Luiz. We are thankful for Margo Odlum's thorough revision and for efficient editorial handling by An Yin.

\section{References}

Alkmim, F.F., Marshak, S., 1998. Transamazonian Orogeny in the Southern São Francisco Craton Region, Minas Gerais, Brazil: evidence for Paleoproterozoic collision and collapse in the Quadrilátero Ferrífero. Precambrian Res. 90, 29-58. https://doi.org/10.1016/S0301-9268(98)00032-1

Andersen, T., Kristoffersen, M., Elburg, M.A., 2018. Visualizing, interpreting and comparing detrital zircon age and $\mathrm{Hf}$ isotope data in basin analysis - a graphical approach. Basin Res. 30, 132-147. https://doi.org/10.1111/ijlh.12426

Armstrong, R.A., Compston, W., de Wit, M.J., Williams, I.S., 1990. The stratigraphy of the 3.5-3.2 Ga Barberton Greenstone Belt revisited: a single zircon ion microprobe study. Earth Planet. Sci. Lett. 101, 90-106.

Avigad, D., Morag, N., Abbo, A., Gerdes, A., 2017. Detrital rutile U-Pb perspective on the origin of the great Cambro-Ordovician sandstone of North Gondwana and its linkage to orogeny. Gondwana Res. 51, 17-29. https://doi.org/10.1016/j.gr.2017.07.001

Belousova, E. a., Griffin, W.L., O’Reilly, S.Y., Fisher, N.I., 2002. Igneous zircon: trace element composition as an indicator of source rock type. Contrib. to Mineral. 
Bracciali, L., Najman, Y., Parrish, R.R., Akhter, S.H., Millar, I., 2015. The Brahmaputra tale of tectonics and erosion: Early Miocene river capture in the Eastern Himalaya. Earth Planet. Sci. Lett. 415, 25-37. https://doi.org/10.1016/j.epsl.2015.01.022

Bracciali, L., Parrish, R.R., Najman, Y., Smye, A., Carter, A., Wijbrans, J.R., 2016. PlioPleistocene exhumation of the eastern Himalayan syntaxis and its domal 'pop-up.' Earth-Science Rev. 160, 350-385. https://doi.org/10.1016/j.earscirev.2016.07.010

Bradley, D.C., 2011. Secular trends in the geologic record and the supercontinent cycle. Earth-Science Rev. 108, 16-33. https://doi.org/10.1016/j.earscirev.2011.05.003

Cavosie, A.J., Valley, J.W., Wilde, S.A., 2005. Magmatic $\delta 180$ in 4400-3900 Ma detrital zircons: A record of the alteration and recycling of crust in the Early Archean. Earth Planet. Sci. Lett. 235, 663-681. https://doi.org/10.1016/j.epsl.2005.04.028

Cawood, P.A., Nemchin, A.A., Strachan, R., 2007. Provenance record of Laurentian passive-margin strata in the northern Caledonides: Implications for paleodrainage and paleogeography. Bull. Geol. Soc. Am. 119, 993-1003. https://doi.org/10.1130/B26152.1

Cawood, P.A., Hawkesworth, C.J., Dhuime, B., 2012. Detrital zircon record and tectonic setting. Geology 40, 875-878. https://doi.org/10.1130/G32945.1

Cherniak, D.J., 2000. Pb diffusion in rutile. Contrib. Miner. Pet. 139, 198-207. https://doi.org/10.1016/S0009-2541(00)00233-3

Condie, K.C., 2014. Growth of continental crust: a balance between preservation and recycling. Mineral. Mag. 78, 623-637. https://doi.org/10.1180/minmag.2014.078.3.11

Condie, K.C., Kröner, A., 2013. The building blocks of continental crust: Evidence for a major change in the tectonic setting of continental growth at the end of the Archean. Gondwana Res. 23, 394-402. https://doi.org/10.1016/j.gr.2011.09.011 
607 Dhuime, B., Hawkesworth, C.J., Delavault, H., Cawood, P.A., 2017. Continental growth

608

609

610

611

612

613

614

615

616

617

618

619

620

621

622

623

624

625

seen through the sedimentary record. Sediment. Geol. 357, 16-32.

https://doi.org/10.1016/j.sedgeo.2017.06.001

Fedo, C.M., Myers, J.S., Appel, P.W.U., 2001. Depositional setting and paleogeographic implications of earth's oldest supracrustal rocks, the $>3.7 \mathrm{Ga}$ Isua greenstone belt, West Greenland. Sediment. Geol. 141-142, 61-77. https://doi.org/10.1016/S0037-0738(01)00068-9

Fielding, L., Najman, Y., Millar, I., Butterworth, P., Garzanti, E., Vezzoli, G., Barfod, D., Kneller, B., 2018. The initiation and evolution of the River Nile. Earth Planet. Sci. Lett. 489, 166-178. https://doi.org/10.1016/j.epsl.2018.02.031

Hart, E., Storey, C., Bruand, E., Schertl, H.P., Alexander, B.D., 2016. Mineral inclusions in rutile: A novel recorder of HP-UHP metamorphism. Earth Planet. Sci. Lett. 446, 137-148. https://doi.org/10.1016/j.epsl.2016.04.035

Hart, E., Storey, C., Harley, S.L., Fowler, M., 2018. A window into the lower crust: Trace element systematics and the occurrence of inclusions/intergrowths in granulite-facies rutile. Gondwana Res. 59, 76-86. https://doi.org/10.1016/j.gr.2018.02.021

Hubert, J.F., 1962. A Zircon-Tourmaline-Rutile Maturity Index and the Interdependence of the Composition of Heavy Mineral Assemblages with the Gross Composition and Texture of Sandstones. J. Sediment. Petrol. 32, 440-450.

Kinnaird, T.C., Prave, A.R., Kirkland, C.L., Horstwood, M., Parrish, R., Batchelor, R.A., 2007. The late Mesoproterozoic-early Neoproterozoic tectonostratigraphic evolution of NW Scotland: the Torridonian revisited. J. Geol. Soc. London. 164, 541-551. https://doi.org/10.1144/0016-76492005-096

Krabbendam, M., Bonsor, H., Horstwood, M.S.A., Rivers, T., 2017. Tracking the evolution of the Grenvillian foreland basin: Constraints from sedimentology and detrital zircon and rutile in the Sleat and Torridon groups, Scotland. Precambrian Res. 295, 67-89. https://doi.org/10.1016/j.precamres.2017.04.027 
Lancaster, P.J., Storey, C.D., Hawkesworth, C.J., Dhuime, B., 2011. Understanding the roles of crustal growth and preservation in the detrital zircon record. Earth Planet. Sci. Lett. 305, 405-412. https://doi.org/10.1016/j.epsl.2011.03.022

Lippert, P.G., 2014. Detrital U-Pb geochronology provenance analyses: case studies in the Greater Green River Basin, Wyoming, and the Book Cliffs, Utah. University of Kansas, 253p.

Ludwig, K.R., 2009. User's Manual for Isoplot 4.15. A Geochronological Toolkit for Microsoft Excel. Berkeley Geochronol. Cent. Spec. Publ. 76.

Luvizotto, G.L., Zack, T., Meyer, H.P., Ludwig, T., Triebold, S., Kronz, A., Münker, C., Stockli, D.F., Prowatke, S., Klemme, S., Jacob, D.E., von Eynatten, H., 2009a.

Rutile crystals as potential trace element and isotope mineral standards for microanalysis. Chem. Geol. 261, 346-369.

https://doi.org/10.1016/j.chemgeo.2008.04.012

Luvizotto, G.L., Zack, T., Triebold, S., Von Eynatten, H., 2009b. Rutile occurrence and trace element behavior in medium-grade metasedimentary rocks: Example from the Erzgebirge, Germany. Mineral. Petrol. 97, 233-249.

https://doi.org/10.1007/s00710-009-0092-z

Martínez Dopico, C.I., Lana, C., Moreira, H.S., Cassino, L.F., Alkmim, F.F., 2017. U-Pb ages and Hf-isotope data of detrital zircons from the late NeoarcheanPaleoproterozoic Minas Basin, SE Brazil. Precambrian Res. 291, 143-161. https://doi.org/10.1016/j.precamres.2017.01.026

McKie, T., 1990. Tidal and storm influenced sedimentation from a Cambrian transgressive passive margin sequence. J. Geol. Soc. London. 147, 785-794. https://doi.org/10.1144/gsjgs.147.5.0785

Meinhold, G., Morton, A.C., Fanning, C.M., Whitham, A.G., 2011. U-Pb SHRIMP ages of detrital granulite-facies rutiles: Further constraints on provenance of Jurassic sandstones on the Norwegian margin. Geol. Mag. 148, 473-480. https://doi.org/10.1017/S0016756810000877 
Morton, A.C., Hallsworth, C., 1994. Identifying provenance-specific features of detrital heavy mineral assemblages in sandstones. Sediment. Geol. 90, 241-256.

Mulder, J.A., Karlstrom, K.E., Halpin, J.A., Merdith, A.S., Spencer, C.J., Berry, R.F., McDonald, B., 2018. Rodinian devil in disguise: Correlation of 1.25-1.10 Ga strata between Tasmania and Grand Canyon. Geology 46, 991-994. https://doi.org/10.1130/G45225.1

Müller, S., Dziggel, A., Sindern, S., Kokfelt, T.F., Gerdes, A., Kolb, J., 2018. Age and temperature-time evolution of retrogressed eclogite-facies rocks in the Paleoproterozoic Nagssugtoqidian Orogen, South-East Greenland: Constrained from U-Pb dating of zircon, monazite, titanite and rutile. Precambrian Res. 314, 468-486. https://doi.org/10.1016/j.precamres.2018.07.002

Nyberg, B., Gawthorpe, R.L., Helland-Hansen, W., 2018. The distribution of rivers to terrestrial sinks: Implications for sediment routing systems. Geomorphology 316, 1-23. https://doi.org/10.1016/j.geomorph.2018.05.007

O'Sullivan, G.J., Chew, D.M., Samson, S.D., 2016. Detecting magma-poor orogens in the detrital record. Geology 44, 871-874. https://doi.org/10.1130/G38245.1

Odlum, M.L., Stockli, D.F., Capaldi, T.N., Thomson, K.D., Clark, J., Puigdefàbregas, C., Fildani, A., 2019. Tectonic and sediment provenance evolution of the South Eastern Pyrenean foreland basins during rift margin inversion and orogenic uplift. Tectonophysics 765, 226-248. https://doi.org/10.1016/j.tecto.2019.05.008

Okay, N., Zack, T., Okay, A.I., Barth, M., 2011. Sinistral transport along the TransEuropean Suture Zone: Detrital zircon-rutile geochronology and sandstone petrography from the Carboniferous flysch of the Pontides. Geol. Mag. 148, 380403. https://doi.org/10.1017/S0016756810000804

Pereira, I., Storey, C., Darling, J., Lana, C., Alkmim, A.R., 2019. Two billion years of evolution enclosed in hydrothermal rutile: Recycling of the São Francisco Craton Crust and constraints on gold remobilisation processes. Gondwana Res. 68, 6992. https://doi.org/S1342937X18303058 
Robinson, D., 1987. Transition from diagenesis to metamorphism in extensional and collision settings. Geology 15, 866-869. https://doi.org/10.1130/0091-7613

Rösel, D., Boger, S.D., Möller, A., Gaitzsch, B., Barth, M., Oalmann, J., Zack, T., 2014a. Indo-Antarctic derived detritus on the northern margin of Gondwana: Evidence for continental-scale sediment transport. Terra Nov. 26, 64-71. https://doi.org/10.1111/ter.12070

Rösel, D., Zack, T., Boger, S.D., 2014b. LA-ICP-MS U-Pb dating of detrital rutile and zircon from the Reynolds Range: A window into the Palaeoproterozoic tectonosedimentary evolution of the North Australian Craton. Precambrian Res. 255, 381-400. https://doi.org/10.1016/j.precamres.2014.10.006

Santos, M., Lana, C., Scholz, R., BUICK, I., Schmitz, M.D., Kamo, S.L., Gerdes, A., Corfu, F., Tapster, S., Wiedenbeck, M., 2017. A New Appraisal of Sri Lankan BB Zircon as Reference Material for LA- ICP-MS U-Pb Geochronology and Lu-Hf Isotope Tracing. Geostand. Geoanalytical Res. 41, 335-358. https://doi.org/10.1111/ijlh.12426

Saylor, J.E., Sundell, K.E., 2016. Quantifying comparison of large detrital geochronology data sets 12, 203-220. https://doi.org/10.1130/GES01237.1

Schmitt, A.K., Zack, T., 2012. High-sensitivity U-Pb rutile dating by secondary ion mass spectrometry (SIMS) with an $\mathrm{O}^{2+}$ primary beam. Chem. Geol. 332-333, 65-73. https://doi.org/10.1016/j.chemgeo.2012.09.023

Stewart, A., 2002. The late Proterozoic Torridonian rocks of Scotland; their sedimentology, geochemistry and origin, Journal of the geological Society Memoirs no 24.

van Gool, J.A.M., Rivers, T., Calon, T., 2008. Grenville Front zone, Gagnon terrane, southwestern Labrador: Configuration of a midcrustal foreland fold-thrust belt. Tectonics 27, 1-35. https://doi.org/10.1029/2006TC002095

Wiedenbeck, M., Allé, P., Corfu, F., Griffin, W.L., Meier, M., Von Quadt, A., Roddick, J.C., Spiegel, W., 1995. Three natural zircon standards for U-Th-Pb, Lu-Hf, 

element and REE analyses. Geostand. Newsl. 19, 1-23.

720 Zack, T., Stockli, D.F., Luvizotto, G.L., Barth, M.G., Belousova, E., Wolfe, M.R., Hinton, R.W., 2011. In situ U-Pb rutile dating by LA-ICP-MS: ${ }^{208} \mathrm{~Pb}$ correction and prospects for geological applications. Contrib. to Mineral. Petrol. 162, 515-530.

723 https://doi.org/10.1007/s00410-011-0609-4

724 


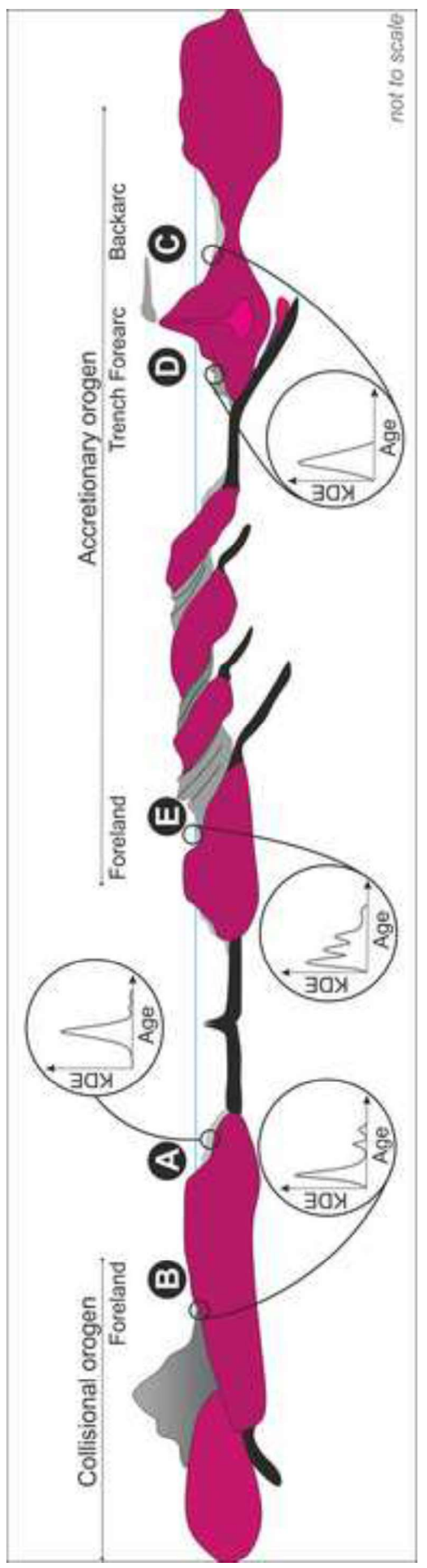


Figure 1. Detrital rutile and zircon KDE examples of a) extensional settings (data from Fielding et al. 2018 from an extensional basin) showing a gaussian unimodal distribution of rutile against a multivariate distribution of detrital zircon, indicating inheritance; b) collisional orogen (data from Bracciali et al., 2016, 2015 from the Himalayas foreland) showing differences in the rutile and zircon KDE. Data include only the 95-105\% concordant data, and ages are either ${ }^{206} \mathrm{~Pb} /{ }^{238} \mathrm{U}$ for ages $<1000 \mathrm{Ma}$ and ${ }^{207} \mathrm{~Pb} /{ }^{206} \mathrm{~Pb}$ for ages $>1000 \mathrm{Ma}$.

Figure 2. Schematic model of different tectonic environments and corresponding detrital rutile KDE curves associated with those basins, namely A-passive margin, B-collisional foreland, C-back-arc, D- trench and fore-arc, and E- accretionary foreland.

Figure 3. Cumulative proportion distributions against growth - deposition ages diagram, modified from Cawood et al. (2012). Coloured fields correspond to different depositional tectonic settings: A. convergent basins, B. collisional basins, C. extensional basins. White dashed lines highlight overlapping fields from different tectonic environments. Two different datasets are projected, with data from Rosël et al. (2014b) and Lippert (2014), corresponding to a backarc and an accretionary foreland basin, respectively. Coloured curves correspond to detrital rutile distribution, and grey curves to detrital zircon. Black arrows indicate significant differences in the cumulative proportions between detrital rutile and zircon from the same dataset for the same age interval. These curves show how detrital zircon cumulative probability distribution curves plot in ambiguous fields, such as the foreland data, projected in the extensional field, whilst detrital rutile from the same sequence are projected in the collisional field.

Figure 4. Depositional tectonic setting diagram based on detrital rutile for A. extensional settings, with data from 1. Rosel et al. (2014a), 2. Meinhold et al. (2011), 3. O'Sullivan et al. (2016), 4. Fielding et al. (2018). ' $S$ ' curve age distributions correspond to extensional settings; $B$. Transition between rift and passive margin detrital rutile age distribution curves in 'suture rift' basins. Arrow points to the period where each curve shows an inflection. Data from Avigad et al. (2017).

Figure 5. Depositional tectonic setting diagram based on detrital rutile for convergent-collisional settings, with data from 1.Rösel et al. (2014b), 2.Okay et al. (2011), 3.Bracciali et al. (2016), 4. and 5. Lippert (2014) Utah and Wyoming sequences, respectively. This allows distinction of convergent and continental foreland basins from foreland basins developed on the accreting side of the orogen. " $r$ " shape age distributions curve corresponding to convergent settings. White dashed line in the diagram marks the age of the exposed basement due to the out of sequence thrusting in the Sevier Foreland (USA).

Figure 6. Rutile and zircon U-Pb age data diagrams for the Torridon Group. KDE and histogram frequency distribution, and cumulative probability of detrital rutile (red; light grey) and zircon (blue, dark grey) for the Diabaig Formation (A and C, respectively); and for the Applecross Formation (B and D, respectively). Zircon data for the Diabaig Formation come from this study and Kinnaird et al. (2007), and for the Applecross Formation come from Lancaster et al. (2011) and Krabbendam et al. (2017). Rutile data for the 
Diabaig Formation come from this study and for the Applecross Formation from this study combined with data from Krabbendam et al. (2017).

Figure 7. Rutile and zircon $\mathrm{U}-\mathrm{Pb}$ age data diagrams for the Ardvreck Grp. KDE and histogram frequency distribution, and cumulative probability of detrital rutile (red/light grey) and zircon (blue/dark grey) for Basal Quartzite Mbr. (A and C, respectively); and for Pipe Rock Mbr. (B and D, respectively). Zircon data come from Cawood et al. (2007) and Lancaster et al. (2011).

Figure 8. U-Pb rutile data retrieved from the metaconglomerate unit of the Sabará Formation; A. Wetherill Concordia showing a Palaeoproterozoic upper intercept and a Pb-loss Palaeozoic lower intercept. These data suggest the existence of a major population at around $2.15 \mathrm{Ga}$ affected by a tectonothermal event at $490 \mathrm{Ma}$; B. Rutile and zircon U-Pb age data diagrams for the Sabará metaconglomerate. KDE and histogram frequency distribution, and cumulative probability of detrital rutile (red/light grey) and zircon (blue/dark grey); C. Cumulative probability curves for detrital rutile and zircon using ${ }^{207} \mathrm{~Pb} /{ }^{206} \mathrm{~Pb}$ ages. Both represent a steep curve with a small gap between deposition age and the main population ages.

Figure 9. Depositional tectonic setting diagram based on detrital rutile for A. extensional settings, with data from 1. Rosel et al. (2014a), 2. Meinhold et al. (2011), 3. O'Sullivan et al. (2016), 4. Fielding et al. (2018), and from this study, 5. Ardvreck Grp (NW Scotland); B. convergent-collisional settings, with data from 1.Rösel et al. (2014b), 2.Okay et al. (2011), 3.Bracciali et al. (2016), 4. and 5.Lippert (2014), and from this study, 6.Sabará Grp. (Brazil) and 7. Torridon Grp (NW Scotland).

Table 1. Summary of the statistical test results obtained using DZstats (Saylor and Sundell, 2016). Rut for rutile, zir for zircon; APC - Applecross, DIA - Diabaig, PR - Pipe Rock, BQ - Basal Quartzite formations. 


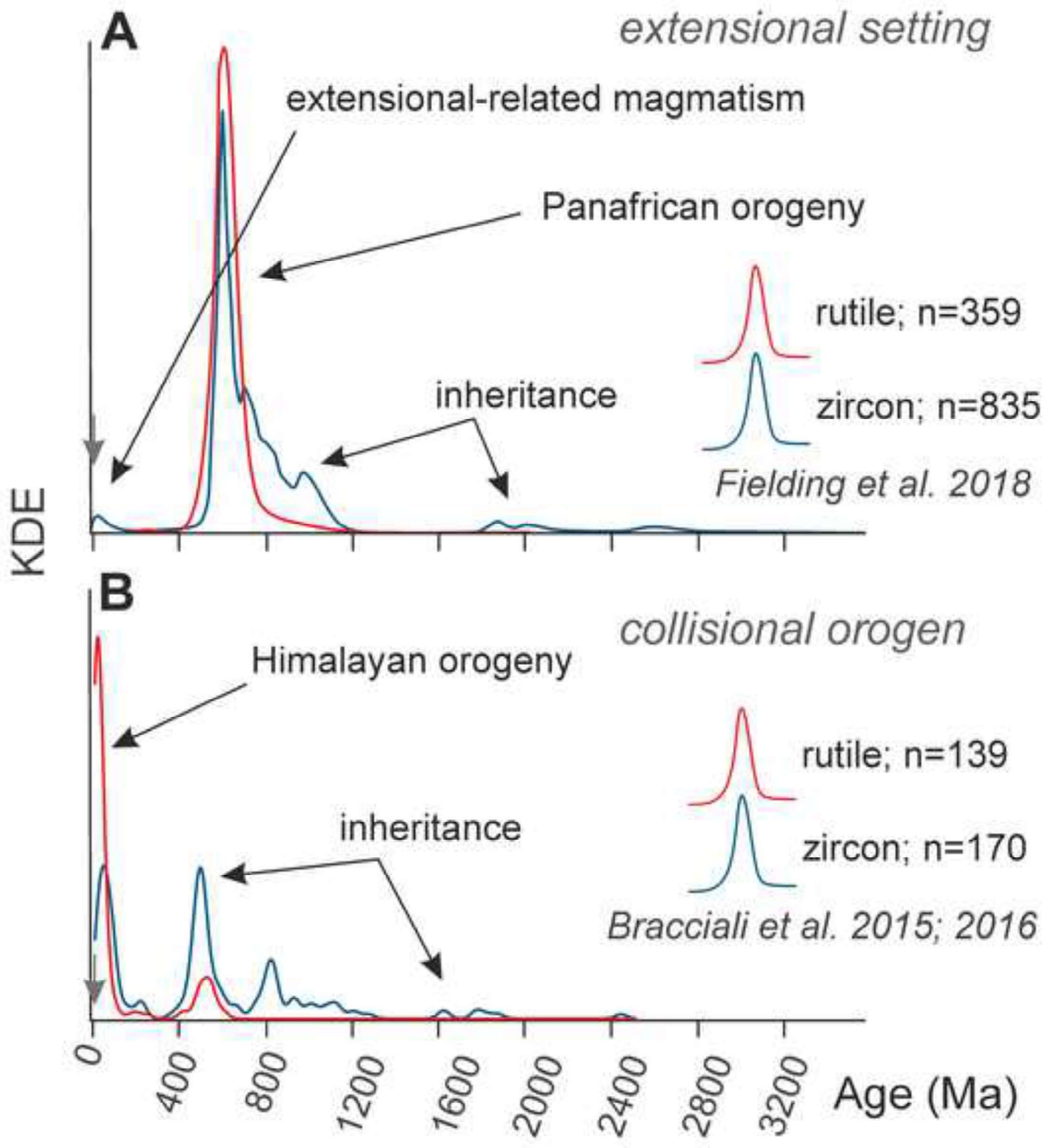




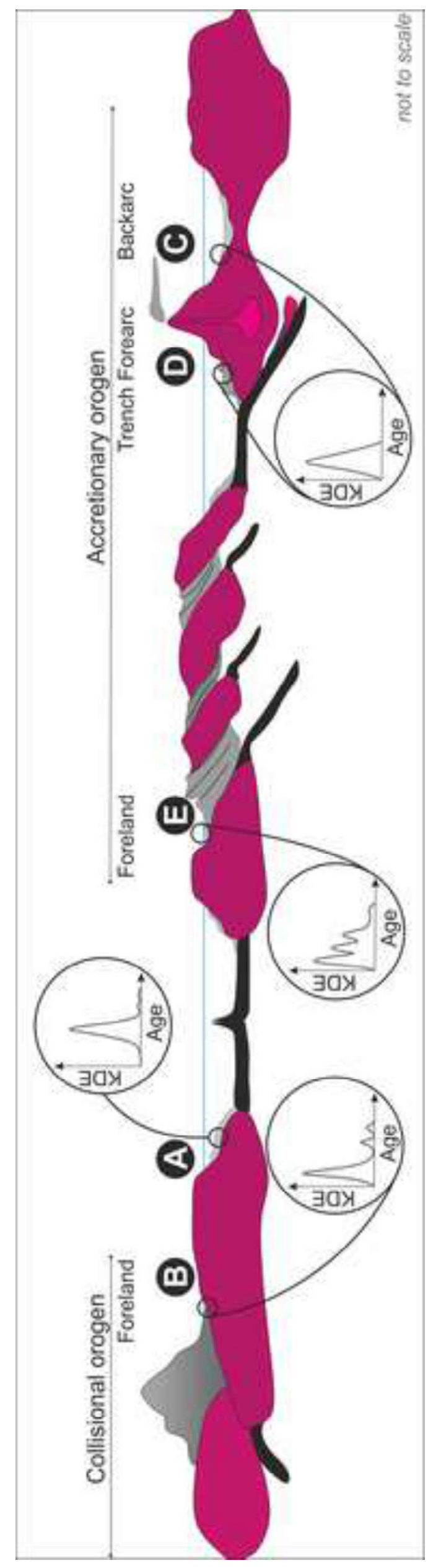

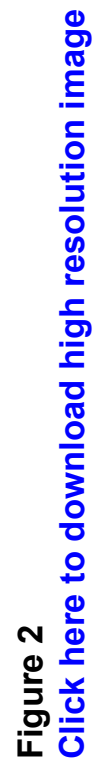




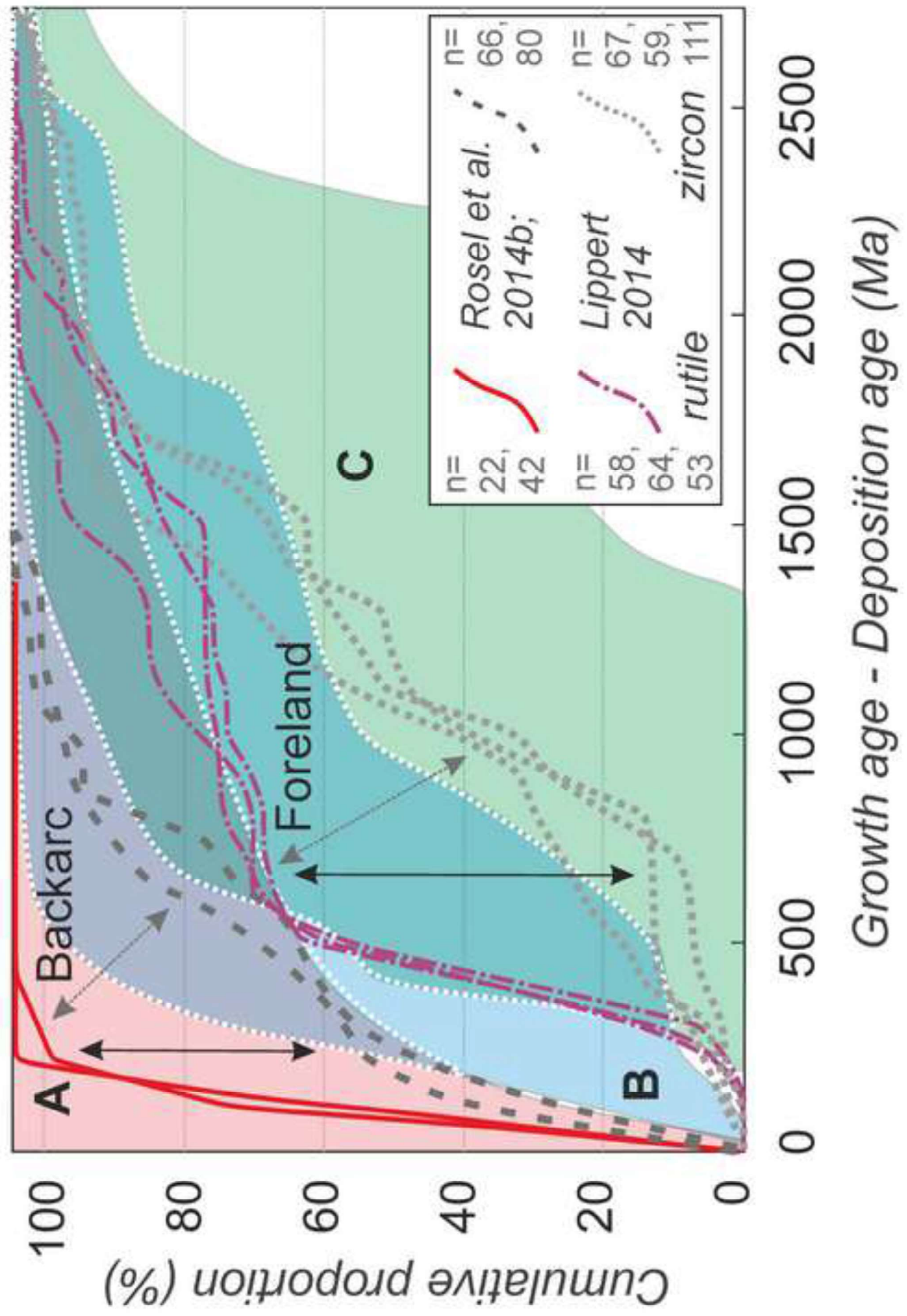




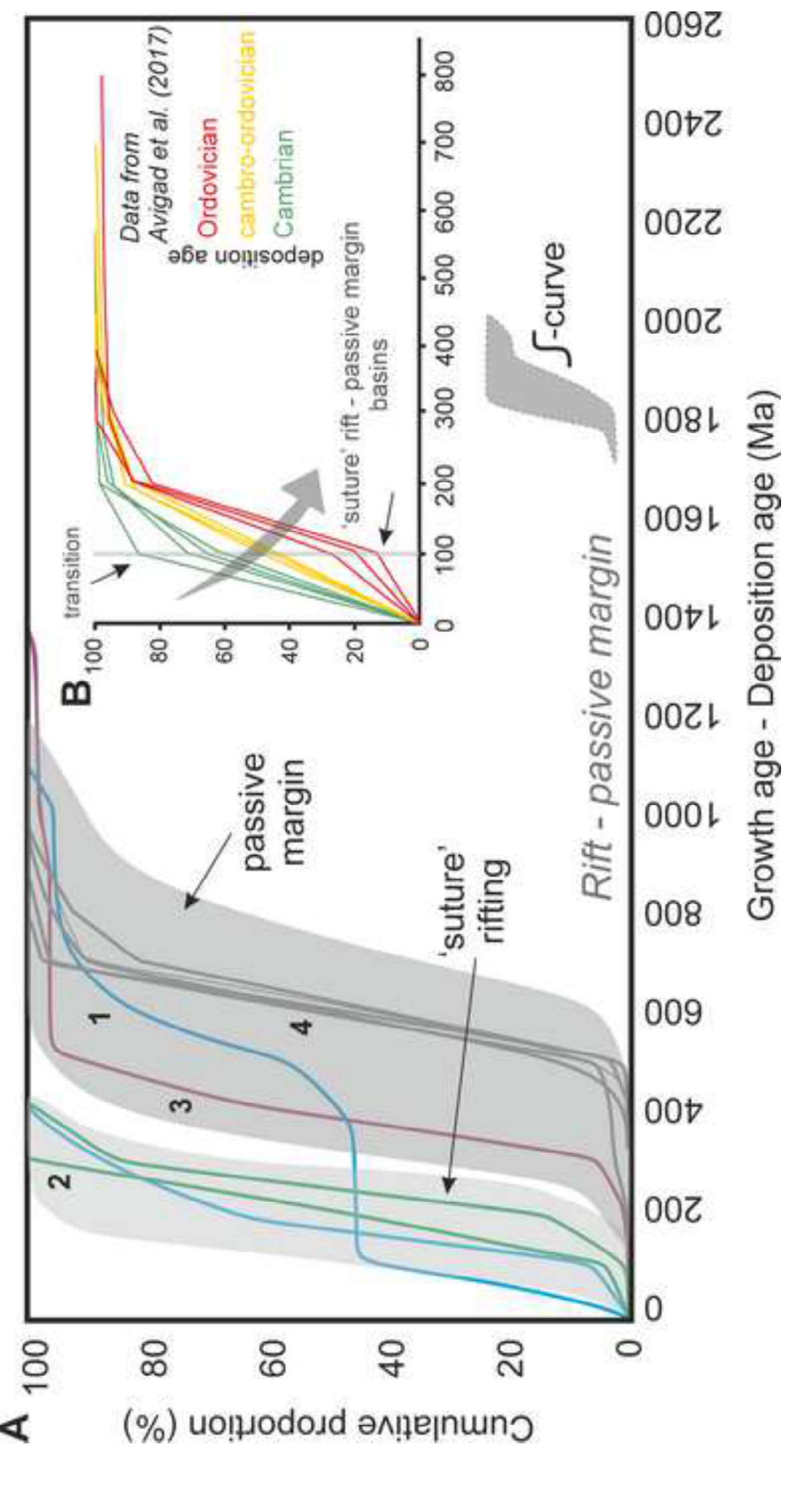




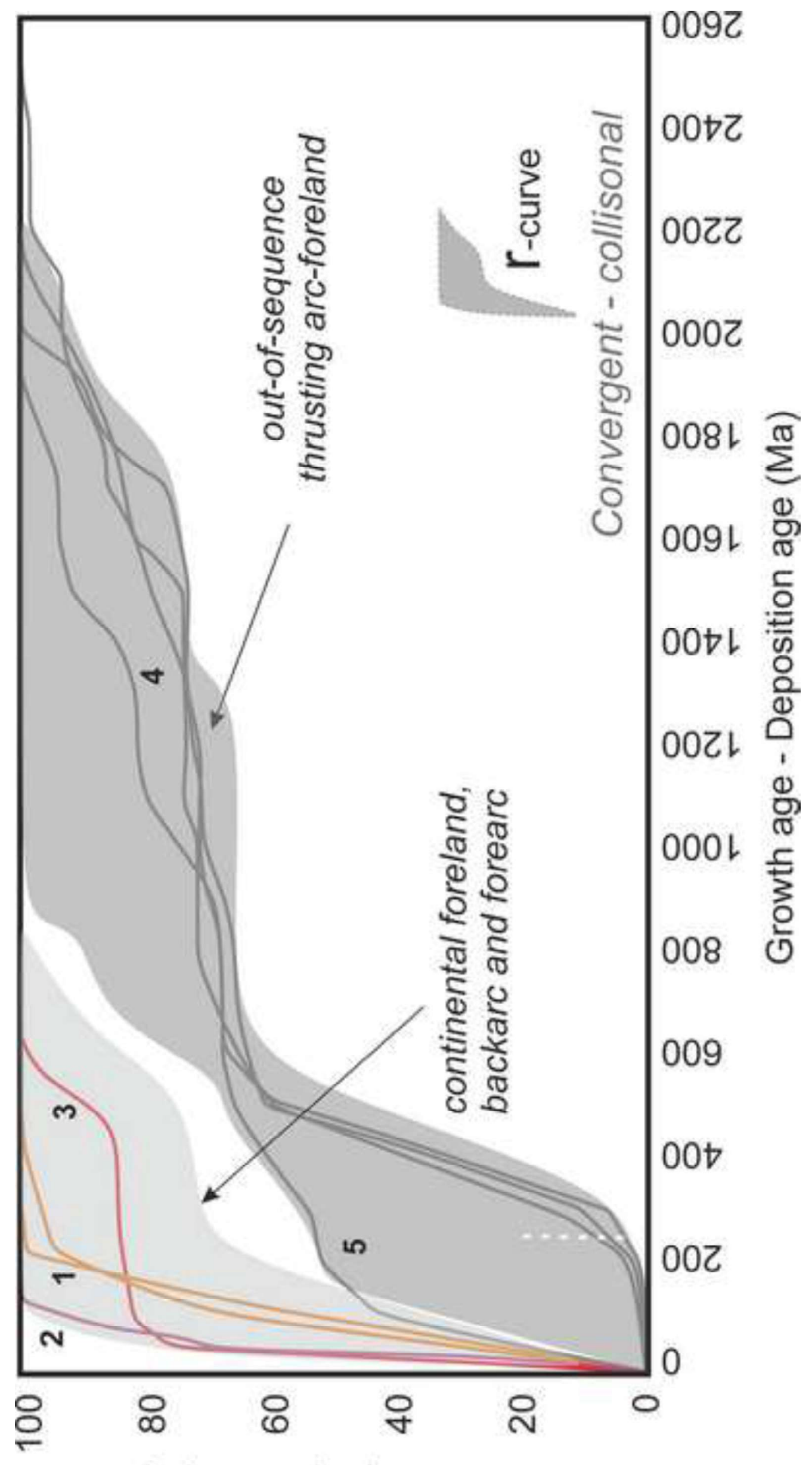

(\%) uo!̣ıodosd әм!̣те|nunว 


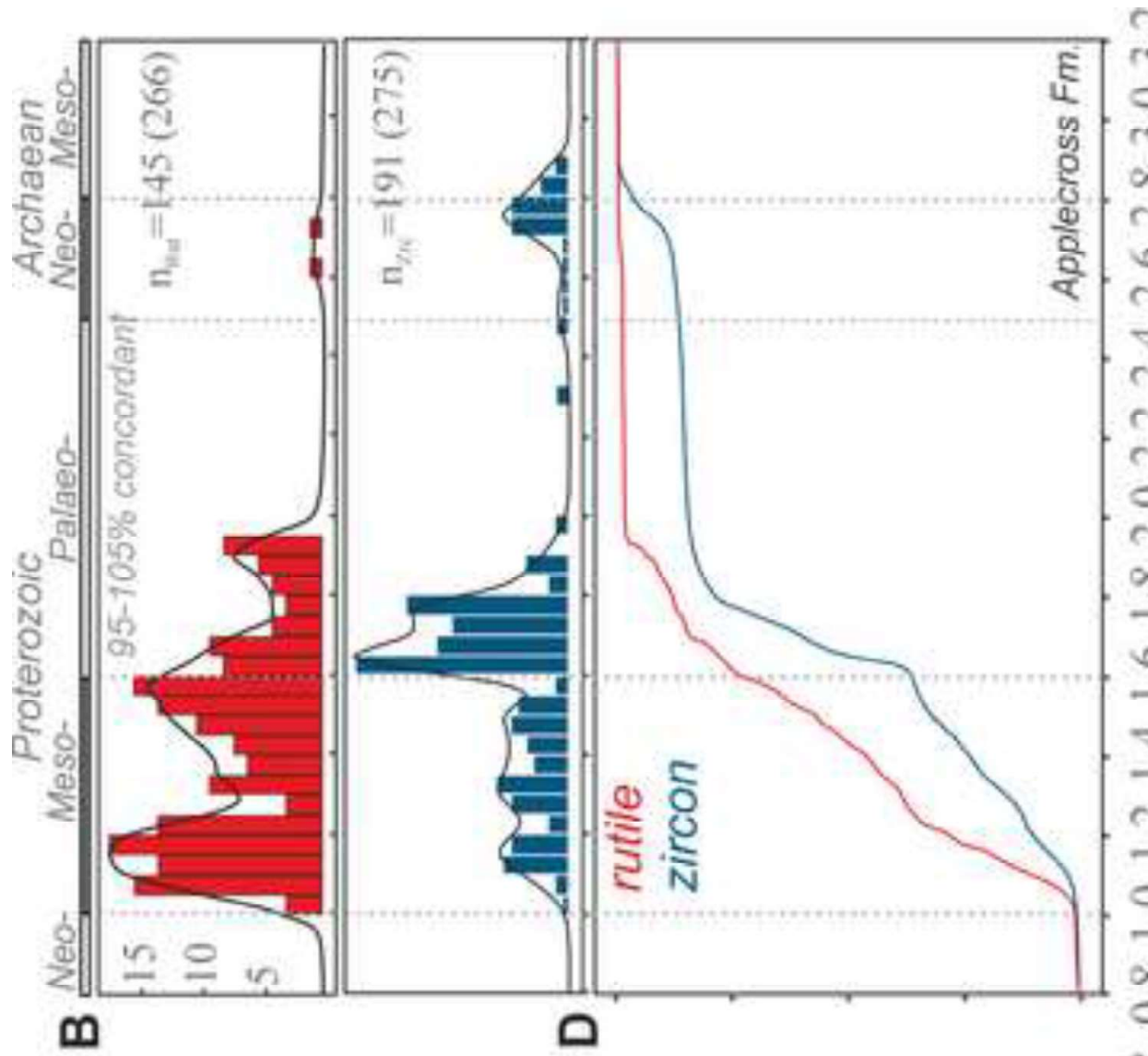

준

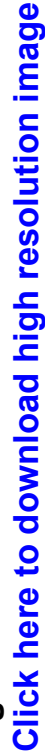

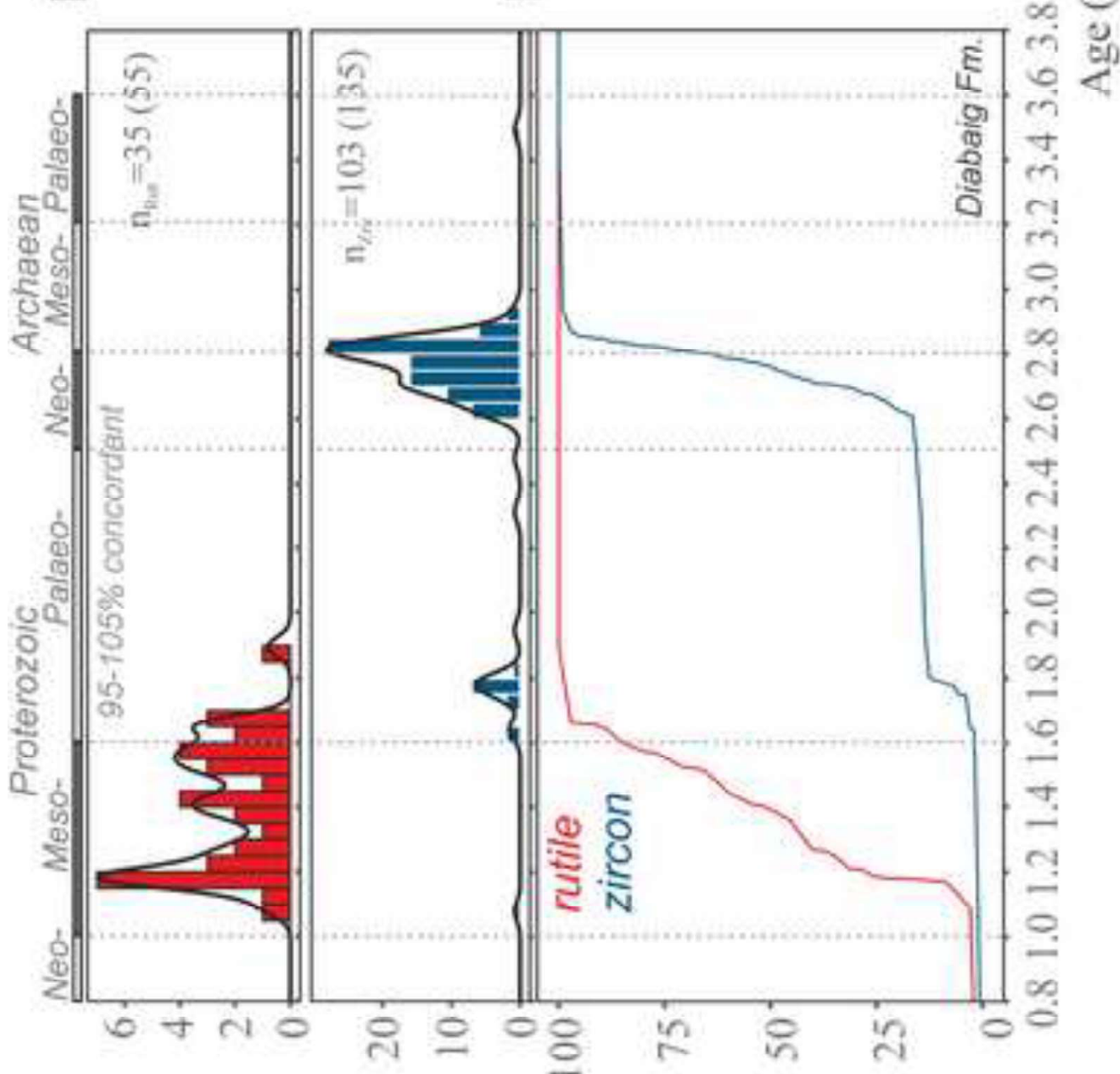

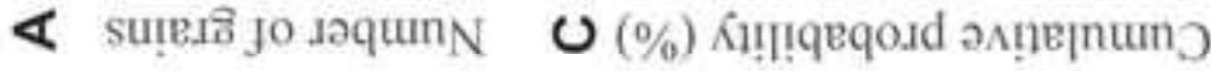




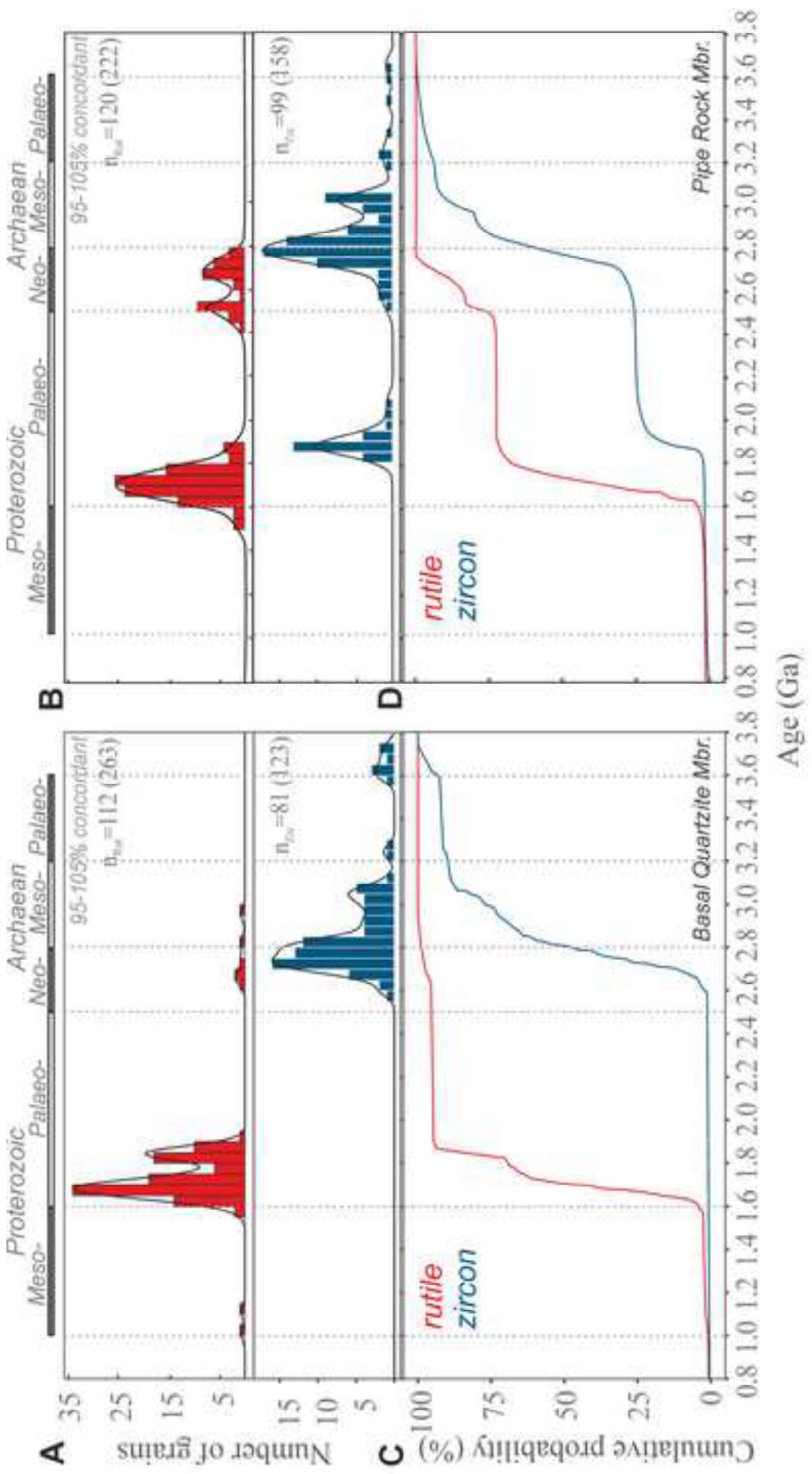




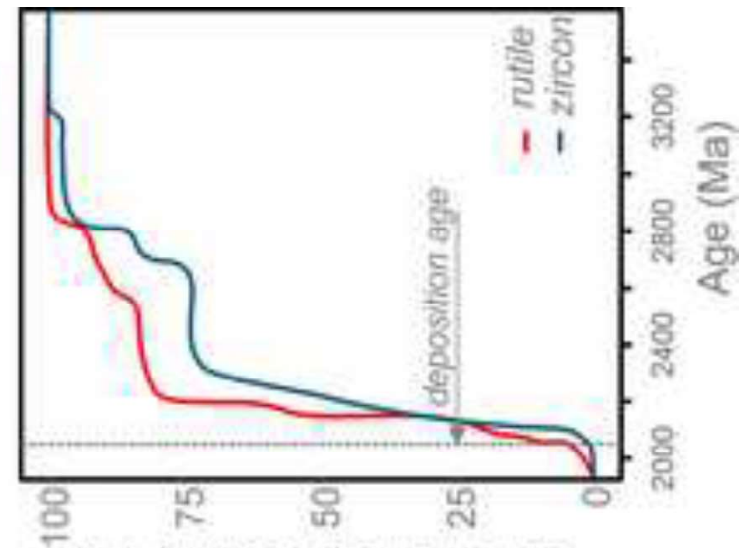

৩ $(\%)$ Kulgegoid angejnung

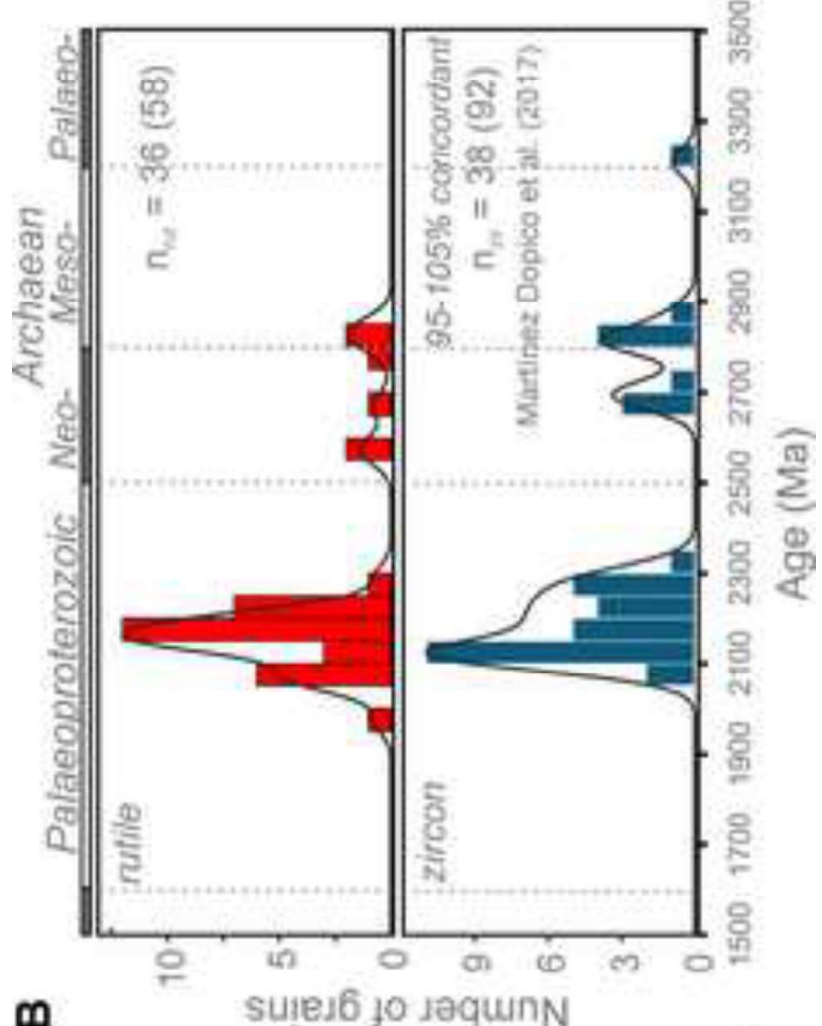

$\boldsymbol{m}$

Suies6 10 IoqunN

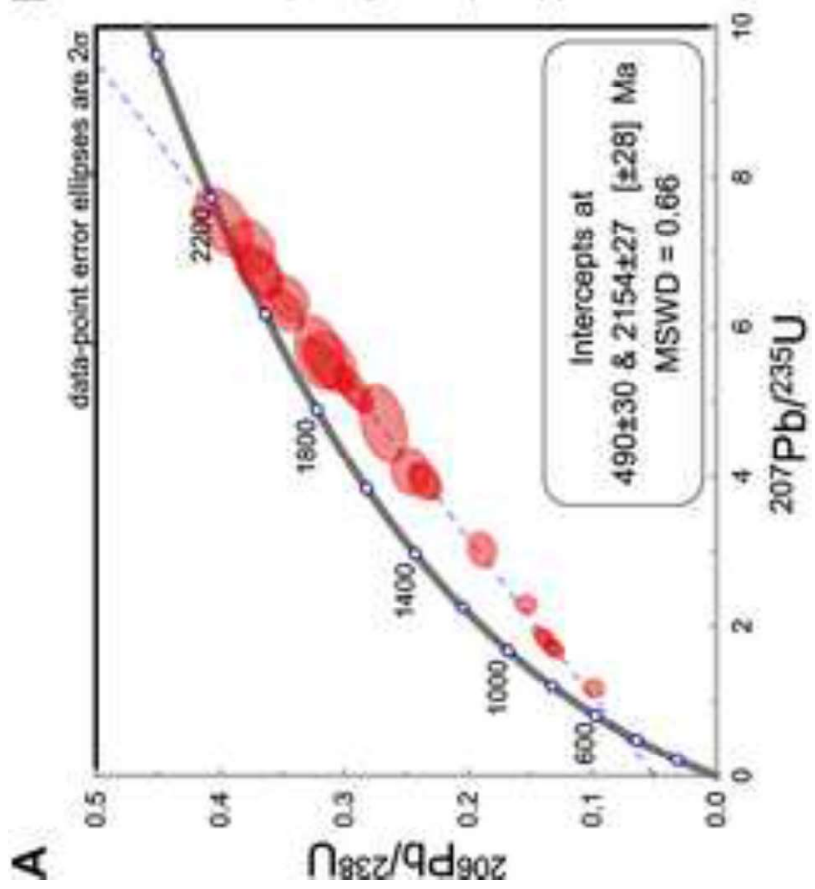

巳 g. 


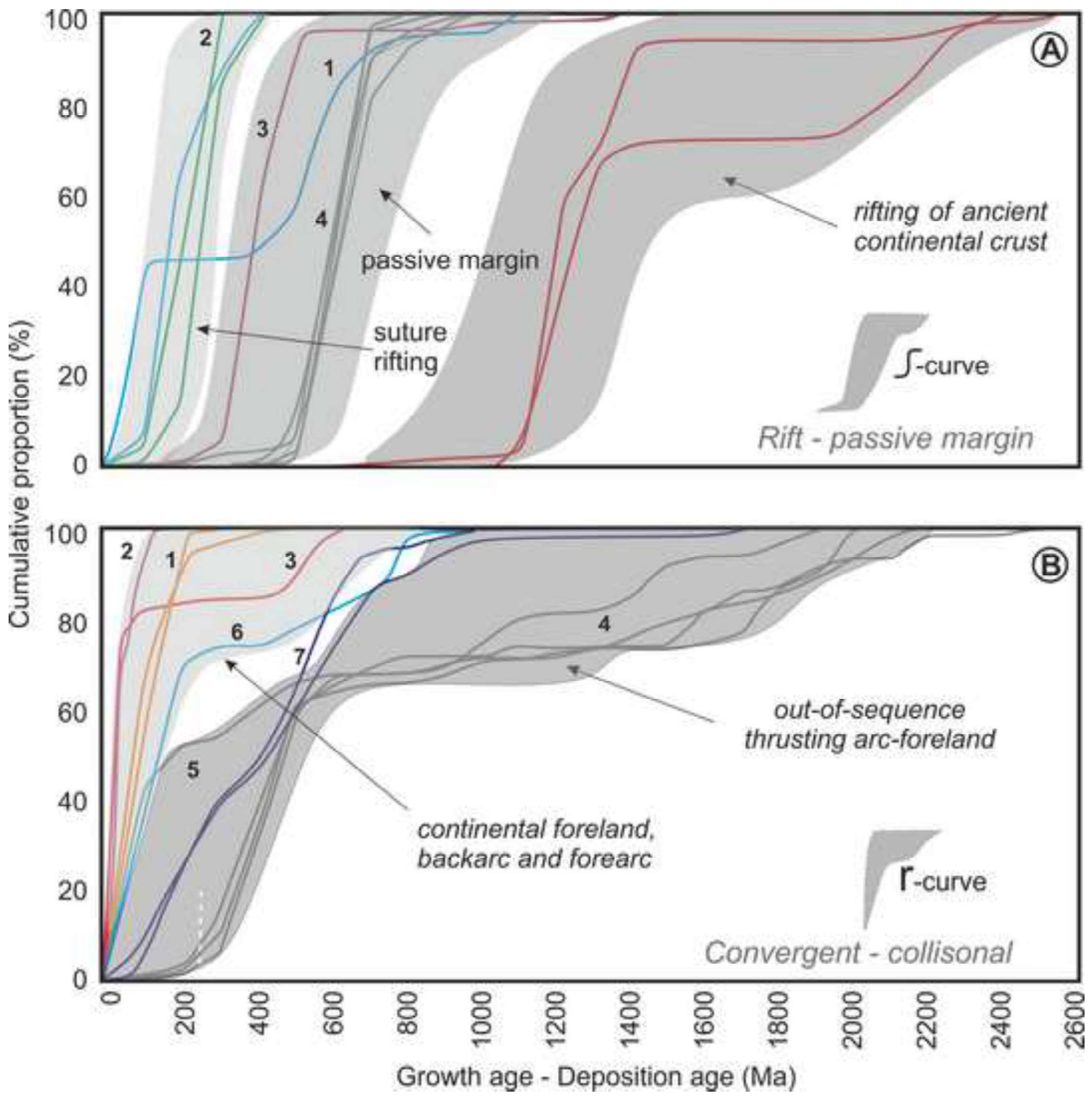




\begin{tabular}{|l|c|c|c|c|}
\hline Populations / test & Cross-correlation KDE & Likeness KDE & Cross-correlation PDP & Similarity PDP \\
\hline Applecross rut-zir & 0.406 & 0.607 & 0.295 & 0.834 \\
\hline Diabaig rut-zir & 0.014 & 0.087 & 0.009 & 0.099 \\
\hline Pipe Rock rut-zir & 0.006 & 0.245 & 0.002 & 0.393 \\
\hline Basal Q. rut-zir & 0.004 & 0.053 & 0.004 & 0.185 \\
\hline APC-DIA rut & $\mathbf{0 . 9}$ & $\mathbf{0 . 8 5 1}$ & $\mathbf{0 . 6 6}$ & $\mathbf{0 . 9 0 3}$ \\
\hline PR-BQ rut & $\mathbf{0 . 6 9 9}$ & $\mathbf{0 . 6 3 5}$ & $\mathbf{0 . 7 3 6}$ & $\mathbf{0 . 8 7 1}$ \\
\hline APC-DIA zir & 0.047 & 0.276 & 0.038 & 0.538 \\
\hline PR-BQ zir & $\mathbf{0 . 7 2 2}$ & $\mathbf{0 . 7 2 8}$ & 0.586 & $\mathbf{0 . 8 0 1}$ \\
\hline
\end{tabular}

